\title{
Impact of Daily Arctic Sea Ice Variability in CAM3.0 during Fall and Winter
}

\author{
DYRE O. DAMMANN \\ Department of Atmospheric Sciences, College of Natural Sciences and Mathematics, Arctic Region Supercomputing Center, \\ University of Alaska Fairbanks, Fairbanks, Alaska \\ UMA S. BHATT \\ Department of Atmospheric Sciences, College of Natural Sciences and Mathematics, and Geophysical Institute, \\ University of Alaska Fairbanks, Fairbanks, Alaska \\ PETER L. LANGEN \\ Danish Climate Centre, Danish Meteorological Institute, Copenhagen, Denmark \\ JEREMY R. KRIEGER \\ Arctic Region Supercomputing Center, University of Alaska Fairbanks, Fairbanks, Alaska \\ XIANGDONG ZHANG \\ International Arctic Research Center, University of Alaska Fairbanks, Fairbanks, Alaska
}

(Manuscript received 2 December 2011, in final form 14 September 2012)

\begin{abstract}
Climate projections suggest that an ice-free summer Arctic Ocean is possible within several decades and with this comes the prospect of increased ship traffic and safety concerns. The daily sea ice concentration tendency in five Coupled Model Intercomparison Project phase 5 (CMIP5) simulations is compared with observations to reveal that many models underestimate this quantity that describes high-frequency ice movements, particularly in the marginal ice zone. To investigate whether high-frequency ice variability impacts the atmosphere, the Community Atmosphere Model, version 3.0 (CAM3.0), is forced by sea ice with and without daily fluctuations. Two 100-member ensemble experiments with daily varying (DAILY) and smoothly varying (SMTH) sea ice are conducted, along with a climatological control, for an anomalously low ice period (August 2006-November 2007). Results are presented for three periods: September 2006, October 2006, and December-February (DJF) 2006/07. The atmospheric response differs between DAILY and SMTH. In September, sea ice differences lead to an anomalous high and weaker storm activity over northern Europe. During October, the ice expands equatorward faster in DAILY than SMTH in the Siberian seas and leads to a local response of near-surface cooling. In DJF, there is a 1.5 -hPa positive sea level pressure anomaly over North America, leading to anomalous northerly flow and anomalously cool continental U.S. temperatures. While the atmospheric responses are modest, the differences arising from high temporal frequency ice variability cannot be ignored. Increasing the accuracy of coupled model sea ice variations on short time scales is needed to improve short-term coupled model forecasts.
\end{abstract}

Corresponding author address: Uma S. Bhatt, Department of Atmospheric Science, College of Natural Sciences and Mathematics, Geophysical Institute, University of Alaska Fairbanks, 903 Koyukuk Dr., Fairbanks, AK 99775-7320.

E-mail: usbhatt@alaska.edu

\section{Introduction}

The recent dramatic decline of Arctic Ocean sea ice area (Comiso and Nishio 2008), extent (Stroeve et al. 2008), and thickness (Rothrock et al. 2008; Kwok and 
Rothrock 2009) has reinvigorated research on the role of sea ice in climate variability and change. While sea ice conditions are primarily a response to atmospheric (e.g., Deser et al. 2000) and oceanic forcing (e.g., Polyakov et al. 2012), global climate model (GCM) studies using fixed sea ice concentration (SIC) and sea surface temperature (SST) lower boundary conditions have demonstrated that the atmosphere responds to changes in sea ice during winter (Alexander et al. 2004; Deser et al. 2004; Magnusdottir et al. 2004) and summer (Bhatt et al. 2008; Benestad et al. 2011; Blüthgen et al. 2012), as well as to future sea ice projections (Singarayer et al. 2006; Deser et al. 2010; Vavrus et al. 2011). The then-record sea ice minimum in 2007 has prompted a rich array of studies examining the impact of reduced sea ice concentration in GCMs (Kumar et al. 2010; Blüthgen et al. 2012), coupled climate models (Sedláček et al. 2012), mesoscale models (Rinke et al. 2006; Strey et al. 2010; Higgins and Cassano 2012), and weather forecast models (Balmaseda et al. 2010; Orsolini et al. 2011).

Modeling studies using imposed sea ice have advanced our understanding of the mechanisms responsible for polar amplification of Arctic warming [see Serreze and Barry (2011) and references therein]. The amplified Arctic surface warming during fall and winter results from reduced sea ice and a warmer ocean caused by increased solar absorption (Screen and Simmonds 2010; Kumar et al. 2010; Screen et al. 2012). Alexeev et al. (2005) demonstrated using aquaplanet simulations that in a warming climate there is increased moisture transport into the Arctic, which also leads to amplification of polar warming. In fixed sea ice model studies this increased poleward energy transport has been shown to lead to a warming of the atmospheric column (Screen et al. 2012) and increased cloud cover (Vavrus et al. 2011) in the middle and upper layers of the troposphere.

Arctic sea ice has implications beyond the Arctic region. Sea ice variations can alter temperature and sea level pressure (SLP), which can further change longrange atmospheric transport and synoptic weather patterns, as well as multiyear oscillations (Balmaseda et al. 2010). Seierstad and Bader (2009) found significant reductions in low-level storminess during winter when comparing future projected (2081-99) seasonal cycles of sea ice with the past (1981-99). Sedláček et al. (2012) decreased model sea ice through imposed albedo reductions to investigate the impact on the atmosphere and ocean in Community Climate System Model, version 3.5 (CCSM3.5). They found that decreased ice induces salinity and temperature anomalies in the North Atlantic Ocean as well as changes in midlatitude storm tracks, which are sensitive to the location of ice anomalies. Based on specified sea ice forcing climate simulations, the atmospheric response to reduced sea ice in the Greenland Sea and increased sea ice in the Labrador Sea resembles the negative phase of the North Atlantic Oscillation (NAO) (Alexander et al. 2004; Deser et al. 2004) and is viewed as a negative feedback on the ice since the original atmospheric forcing pattern found in observations was the positive phase of the NAO (Deser et al. 2000). In contrast, sea ice extent anomalies in the North Pacific Ocean induce surface flux anomalies that excite a Rossby wave train (Honda et al. 1999), which has a positive feedback on the ice (Alexander et al. 2004). For example, if sea ice area is above normal, then the induced circulation change over the ice area would act to increase the ice further. Using the ECHAM5 model, Petoukhov and Semenov (2010) varied sea ice from $0 \%$ to $100 \%$ in the Barents-Kara Seas and found that the atmospheric circulation response was highly nonlinear, suggesting that the atmosphere is quite sensitive to sea ice cover.

Future projections suggest that an ice-free summer Arctic is possible within the next few decades (e.g., Holland et al. 2006b). The prospect of increased ship traffic through the Arctic motivated by shortened transport time between Asia and Europe has raised concerns about border security (e.g., Knell 2008), but has also generated an interest in the prediction of seasonal and shorter-time scale sea ice forecasts. Sea ice forecasts are also driven by activities related to oil and gas development as well as by Arctic inhabitants that depend on the sea ice for access to food (Druckenmiller et al. 2010). Sea ice models that have been developed primarily for climate-scale investigations are now being employed for shorter-time scale forecasts (e.g., Hunke and Lipscomb 2010) as the community works toward continuous daily-to-seasonal forecasts. The time is right to more closely examine sea ice concentration variability on daily time scales in this class of climate models.

Accurate sea ice predictions are necessary for a precise seasonal forecast of the extratropical summer, and to this end Balmaseda et al. (2010) employed daily varying sea ice conditions in a long-range weather forecast model. While sea ice concentration can appear to change slowly throughout the seasons, a closer look at observations indicates that rapid changes occur over relatively large areas on a daily basis. The novel aspects of the current study include an evaluation of daily sea ice variability in a set of coupled model simulations from phase 5 of the Coupled Model Intercomparison Project (CMIP5) and an investigation of the atmospheric response to daily ice variations. This has not been well explored in climate models, which typically specify monthly mean sea ice concentration that is then interpolated to construct smoothed daily values. In 
TABLE 1. List of CMIP5 models used in this study to construct Fig. 1.

\begin{tabular}{|c|c|c|}
\hline Modeling center & $\begin{array}{l}\text { Model version and resolution of sea ice model } \\
\text { experiment identification }\end{array}$ & Model years analyzed \\
\hline $\begin{array}{l}\text { Canadian Centre for Climate Modelling and } \\
\text { Analysis (CCCma), Victoria, Canada }\end{array}$ & $\begin{array}{l}\text { Canadian climate model, version } 4 \text { (CanCM4), } \\
\text { T63 Gaussian grid, decadal from } 1980\end{array}$ & $1981-2010$ \\
\hline $\begin{array}{l}\text { Met Office Hadley Centre, Devon, United } \\
\text { Kingdom }\end{array}$ & $\begin{array}{l}\text { Met Office Hadley Centre Global Environmental Model, } \\
\text { version } 2 \text { (Carbon Cycle) (HadGEM2-CC) } 1^{\circ} \times 1^{\circ} \text {, historical }\end{array}$ & $1950-79$ \\
\hline $\begin{array}{l}\text { NASA Goddard Institute for Space Studies } \\
\text { (GISS), New York, United States }\end{array}$ & $\begin{array}{l}\text { GISS Model E, coupled with Russell ocean model (GISS-E2-R), } \\
1^{\circ} \times 1.25^{\circ}, \text { historical }\end{array}$ & $1950-74$ \\
\hline $\begin{array}{l}\text { NOAA Geophysical Fluid Dynamics } \\
\text { Laboratory (GFDL), Princeton, } \\
\text { United States }\end{array}$ & $\begin{array}{l}\text { GFDL Earth System Model (ESM2G-C2_all_historical_HC2), } \\
\sim 1^{\circ} \times 1^{\circ} \text { tripolar grid, historical (run1) }\end{array}$ & $1951-80$ \\
\hline $\begin{array}{l}\text { Institute of Numerical Mathematics (INM), } \\
\text { Moscow, Russia }\end{array}$ & INM Coupled Model, version $4(\mathrm{CM} 4), 1^{\circ} \times 0.5^{\circ}$, historical & $1950-79$ \\
\hline
\end{tabular}

addition, this is a timely exercise as the demands for short-term forecasts and long-term projections are growing.

Before focusing on the details of a single model, it is worthwhile to demonstrate how well coupled climate models simulate day-to-day sea ice variability. While vastly improved from CMIP3, sea ice availability at a daily time resolution is limited in the CMIP5 archive, impacting what could be presented here. All the analyzed data are from historical runs that span 25-30 years between 1950 and 2010 and most models have a sea ice resolution of approximately $1^{\circ} \times 1^{\circ}$ (Table 1 ). The analysis is presented on the original model grid to avoid artificial sea ice from interpolation (Massonnet et al. 2012) and the goal is to qualitatively show that underestimating high-frequency sea ice variability is common in climate models. Figure 1 displays the magnitude of the July-August daily sea ice tendency for observations and five CMIP5 historical simulations. The daily tendency magnitude is evaluated by taking the root-meansquare of the differences between sea ice concentration on successive days over multiple years [see Eq. (1)]. Overall, the models underestimate the day-to-day sea ice variability with the exception of INM-CM4 (Fig. 1f; expansions of CMIP5 models are given in Table 1), suggesting that this deficiency is common to many climate models. Substantial additional analysis would be required to understand why the CMIP5 models behave as they do, and this is beyond the scope of the present study. One may next ask whether capturing the highfrequency variations in the sea ice really matters in terms of the impact on the atmosphere. To examine this question, this study presents a set of sensitivity experiments investigating the atmospheric response to daily and smoothly varying sea ice during fall 2006 (SeptemberOctober) and winter 2006/07 (December-February) using the Community Atmosphere Model, version 3.0 (CAM3.0).

\section{Methods}

\section{a. Model for specified sea ice experiments}

This study employs the Community Atmosphere Model, version 3.0 (Collins et al. 2006b), interactive with version 3 of the Community Land Model (CLM3) (Dickinson et al. 2006), for the prescribed sea ice and SST simulations. The ocean and ice models are replaced by data models; SST and SIC values are specified as boundary conditions. Ice surface temperatures are calculated using a surface energy balance and snow accumulates on the ice surface impacting the albedo. A known shortcoming of fixed SST experiments is reduced near-surface atmospheric variability that results from excessive damping of air temperature (e.g., Bhatt et al. 1998; Barsugli and Battisti 1998), as well as the violation of the top of the atmosphere (TOA) energy balance. Imposing sea ice lower boundary conditions also leads to TOA imbalances, which is an accepted limitation of this type of modeling exercise. It can be argued in this study that these TOA imbalances are similar in the two sensitivity studies because of the small forcing differences, thus minimizing the impact when the difference between the two experiments is calculated. All simulations in this study have a horizontal resolution of T85 (corresponding to approximately $1.4^{\circ} \times 1.4^{\circ}$ ) and 26 levels in the vertical. Hack et al. (2006) showed that the Arctic atmospheric circulation compares better with observations at T85 than T42.

The data ocean component of CAM3.0 was modified to read in daily values of sea ice concentration and sea surface temperature. The standard procedure for running fixed sea ice experiments with CAM3.0 is to read in monthly ice and SST fields that are then interpolated to obtain daily values. The modified code employed here reads in two-dimensional sea ice and SST fields on each day of the model integration at 0000 UTC, and these values are then used to force the model for the next $24 \mathrm{~h}$. Apart from the changed frequency of the input boundary 
a) Observations

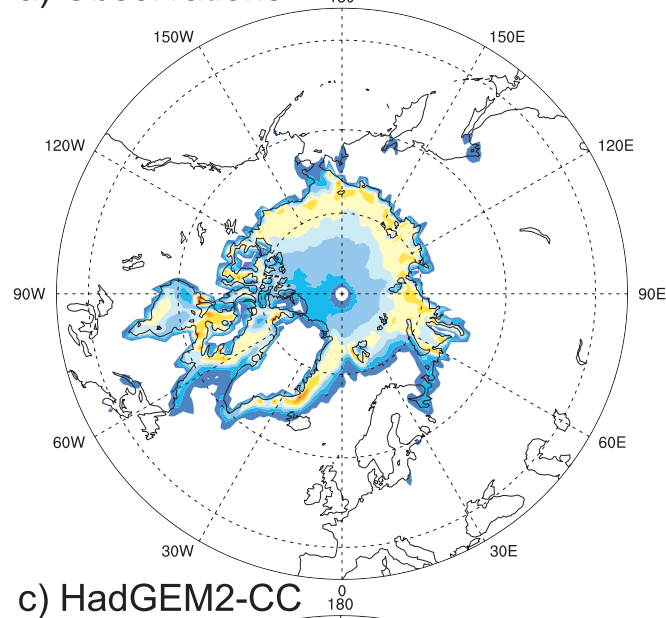

c) HadGEM2-CC

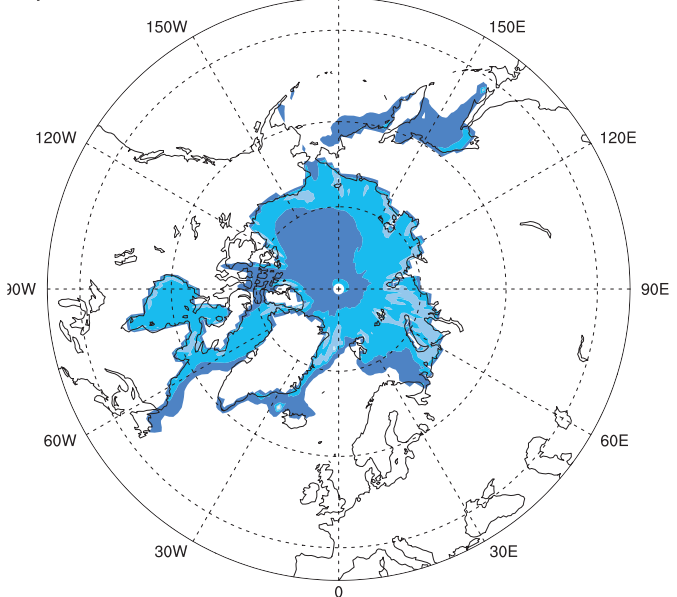

e) ESM2G-C2_all_historical_HC2

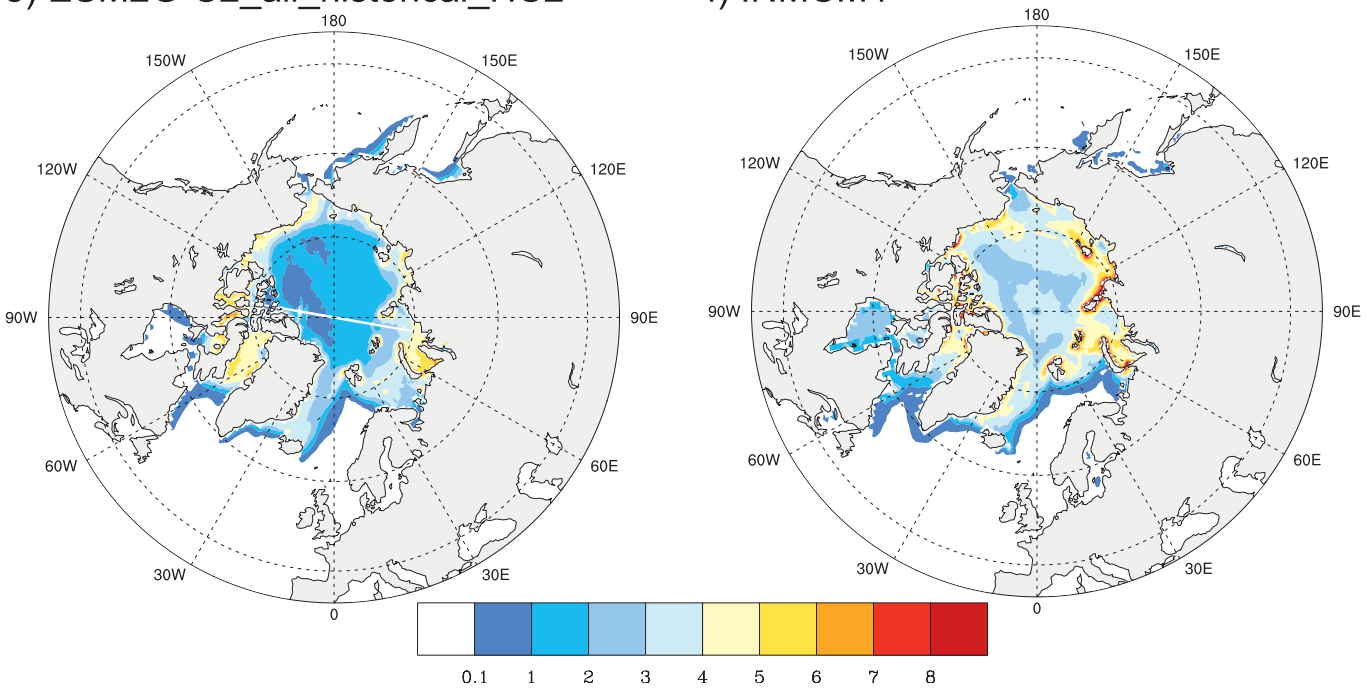

b) CanCM4

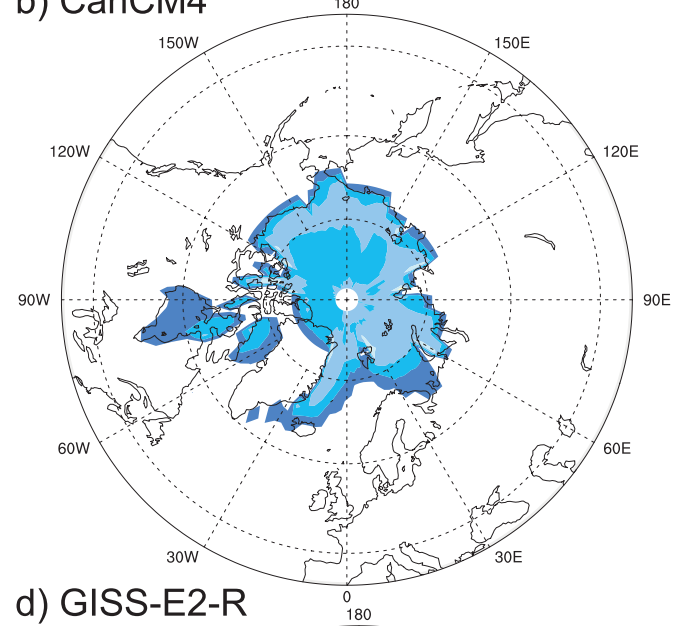

d) GISS-E2-R

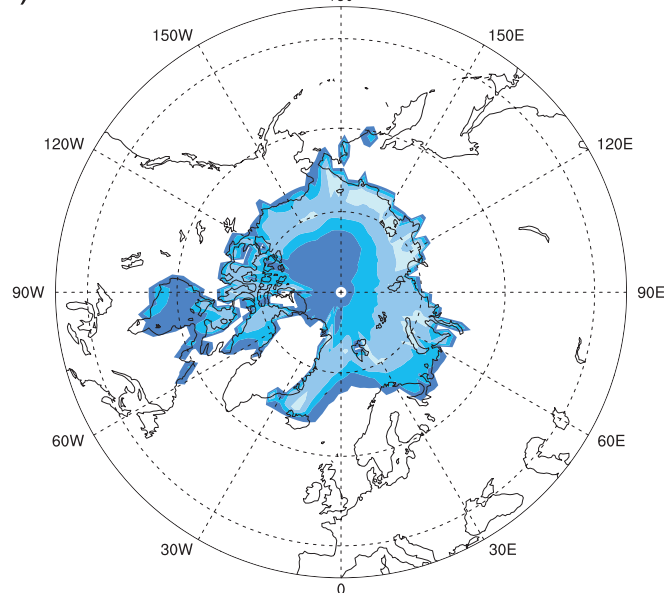

f) INMCM4

FIG. 1. July-August daily sea ice concentration (SIC) tendency [see Eq. (1)] for (a) observations based on passive microwave data and five CMIP5 multiyear historical simulations, (b) CanCM4 (1981-2010), (c) HadGEM2-CC (1950-79), (d) GISS-E2-R (1950-74), (e) ESM2G-C2_all_historical_HC2 (1951-80), and (f) INM-CM4 (1950-79). Additional information about CMIP5 models, including expansions, is given in Table 1. Plot units are percentage ice concentration per day. 
conditions, the model treats and uses the fields in the same manner as the standard distribution of the CAM3.0 code.

\section{b. Observed ice and ocean boundary conditions}

The daily Arctic sea ice concentration dataset from 1982 to 2007 used in this study is derived from passive microwave satellite measurements [Special Sensor Microwave Imager (SSM/I)] through the bootstrap algorithm on a $25-\mathrm{km}$-resolution polar-projected grid (Comiso and Nishio 2008) and represents the most consistent available source of Arctic sea ice data. The Antarctic sea ice concentration is from the Hadley Centre Ice and Sea Surface Temperature data set version 1.1 (HadISST 1.1). The sea surface temperature data come from the National Oceanic and Atmospheric Administration (NOAA) Extended Reconstructed Sea Surface Temperature (ERSST), version $3 b$ (Smith et al. 2008) http://www.esrl.noaa.gov/psd/data/gridded/data. noaa.ersst.html, dataset. This NOAA SST file is constructed from International Comprehensive OceanAtmosphere Data Set (ICOADS) release 2.4 SST data and employs improved statistical methods to construct a continuous dataset from sparse data. The climatological annual cycle of monthly Antarctic sea ice and SST were splined to produce daily values and combined with the Arctic sea ice concentration to form a single input file. The boundary forcing was spatially interpolated to the model T85 grid.

\section{c. Experimental setup}

Three simulations using the modified version of CAM3.0 were integrated to investigate the atmospheric response to climatological, daily varying (DAILY), and smoothly varying $(\mathrm{SMTH})$ sea ice concentration. All simulations were forced with the mean annual cycle of Antarctic sea ice and global SST. The control (CTRL) is a continuous simulation while DAILY and SMTH are ensemble runs that are initialized with 100 different 1 July conditions from the CTRL simulation. Analysis of the 100-ensemble member simulations begins with 1 August (Table 2).

The modified version of CAM3.0 was forced with a repeated annual cycle of daily SIC and SST (1982-2007) to form the control simulation. In the DAILY experiment, the model was forced with daily SIC in the Arctic from 1 July 2006 to 30 November 2007. Fall 2006 and winter 2006/07 were chosen for this study because the sea ice extent was well below average and this period is studied less than the record-setting fall of 2007. In regions where the ice extent was smaller than the mean extent, the exposed ocean was set to the climatological SST; when the ice area expanded above normal, SSTs were blended from $-1.8^{\circ} \mathrm{C}$ (the temperature at which
TABLE 2. Configuration of sea ice and SST in simulations. Climatological global SST and Antarctic sea ice were identical in all experiments and were constructed by using a cubic spline on 12 monthly long-term means (1982-2007) to construct daily values.

\begin{tabular}{lc}
\hline \multicolumn{1}{c}{ Integration } & \multicolumn{1}{c}{$\begin{array}{c}\text { Sea ice boundary } \\
\text { conditions in the Arctic }\end{array}$} \\
\hline $\begin{array}{l}\text { CTRL (Control) } \\
\text { (100 years) }\end{array}$ & $\begin{array}{c}\text { Monthly mean sea ice concentration } \\
\text { splined to daily values using } \\
\text { averaged 1982-2007 ice } \\
\text { concentration. }\end{array}$ \\
DAILY (July & $\begin{array}{c}\text { Daily varying sea ice concentration } \\
\text { over the period 1 Jul 2006 to }\end{array}$ \\
2006-November 2007) & 30 Nov 2007. \\
(100-member & Smoothed daily varying sea ice \\
SMTH (July & concentration (adjusted running \\
2006-November 2007) & average of daily values) over the \\
(100-member & period 1 Jul 2006 to 30 Nov 2007. \\
ensemble) &
\end{tabular}

there is $100 \%$ ice cover in CAM3.0) at the ice edge with climatological values from two grid boxes $\left(2.8^{\circ}\right.$ latitude and $2.8^{\circ}$ longitude) seaward from the ice edge. This method was used previously in Alexander et al. (2004) and Bhatt et al. (2008) to minimize abrupt gradients in surface forcing. SSTs were not changed to observed values since the goal of this study focused on ice variability. In SMTH, the model was forced with smoothed Arctic sea ice constructed by adjusting the 30-day running average of daily sea ice to ensure the monthly average at each grid point differed by less than $\pm 0.5 \%$ with DAILY. Using this method, the difference in atmospheric response between DAILY and SMTH is almost entirely caused by differences in sea ice forcing variability and not to differences in the monthly average sea ice concentration. When the smoothed sea ice was constructed by interpolating monthly means to daily values using a cubic spline, the monthly mean sea ice concentration from DAILY and SMTH differs by up to $5 \%$ at a given grid point. This happens because sea ice is constrained between $0 \%$ and $100 \%$ and splining can overshoot these bounds, making model responses difficult to interpret because the differences in boundary forcing arise from both the temporal ice variability and monthly mean values.

\section{d. Other methodology}

The significance of the atmospheric response in the experiments is evaluated using a pooled variance $t$ test. The number of ensemble members needed to achieve robust significance is dependent on the ensemble average of the response and the standard deviation of a given variable. Simulations of variables with higher intrinsic variability require more ensemble members to achieve significance (Alexander et al. 2004; Sardeshmukh et al. 2000), and while the difference in SLP response between 
DAILY and SMTH is typically $\sim 1 \mathrm{hPa}$, its standard deviation reaches $\sim 6 \mathrm{hPa}$ in the Arctic $\left(70^{\circ}-90^{\circ} \mathrm{N}\right)$ during fall. It is not surprising that the signal is relatively small because the boundary forcing differences between the DAILY and SMTH are small. Coupling this modest response with high variability, 100 ensemble members were necessary to establish significance.

The day-to-day sea ice variability in July-August in CMIP5 (Taylor et al. 2012) models was presented in the introduction, demonstrating that the underestimation of daily ice variability is common to many climate models. A more in-depth analysis of additional seasons for the Community Climate System Model, version 3.0 (CCSM3.0) (Collins et al. 2006a), is presented in the results section below. The CCSM family of models is widely used and was developed at the National Center for Atmospheric Research (NCAR) in collaboration with other national laboratories and university partners. CCSM3.0 consists of five individual components for modeling the atmosphere (CAM3.0; Collins et al. 2006b), ocean [Parallel Ocean Program (POP); Smith and Gent 2002], land surface (CLM3) (Dickinson et al. 2006), and sea ice [Community Sea Ice Model, version 5 (CSIM5); Briegleb et al. 2004], which exchange data with each other through the flux coupler (CPL6; Kauffman and Large 2002).

\section{Results}

\section{a. Evaluation of CCSM ice variability}

The sea ice climatology and daily tendencies from a fully coupled CCSM3.0 (Collins et al. 2006a) twentiethcentury control simulation (b30.004) were evaluated over a 27-yr period (model years 1973-99). The higherresolution observational data were interpolated to the model T85 grid after climatology and daily tendencies were calculated in order to quantify differences between the model and observations.

One of the most striking features of observed daily sea ice is its horizontal movement and the resultant opening and closing of leads, arising from wind forcing and underlying ocean currents. To quantify this day-to-day variability, the daily SIC tendency is computed by first calculating the difference in sea ice concentration on successive days. This quantity is then used to evaluate how daily changes are represented in the model. Equation (1) describes sea ice concentration tendency by

$$
\frac{\partial \operatorname{SIC}}{\partial t}=\frac{1}{m-1} \sum_{d=2}^{m} \sqrt{\frac{1}{n} \sum_{y=1}^{n}[\operatorname{SIC}(d, y)-\operatorname{SIC}(d-1, y)]^{2}},
$$

taking the root-mean-square of $n$ years of differences between one day and the next. The one-day tendencies are averaged over a specified time period. In Equation (1), $d$ represents individual days and $y$ individual years, while $m$ and $n$ are the number of days and years used in a given calculation, respectively. The results are displayed in Fig. 2; the observations exhibit generally higher variability than the model for all seasons. Around the North Pole there is a data gap in available observational satellite data, which has grown smaller over time. The model consistently underestimates daily variations along the marginal ice zone during summer and fall (middle and lower rows). During winter [December-February (DJF)], CCSM3.0 displays higher variability at the southern ice edge (see top right panel in Fig. 2) that results from excessive mean ice in CCSM3.0 relative to observations (Holland et al. 2006a; Dammann 2011). Daily sea ice concentration tendency was calculated and found to be lower in a twentieth-century simulation of CCSM4.0 (not shown) than in observations; however, CCSM4.0 was closer to the observations than CCSM3.0. SIC variability is underestimated in CCSM3.0 on day-today time scales. This leads to the question: Does the underestimated ice variability have a significant impact on the atmosphere?

\section{b. Model response during fall (September-October)}

\section{1) SEPTEMBER}

The September 2006 monthly mean ice concentration for DAILY (almost identical to SMTH) is shown in Fig. 3a. The daily SIC tendency anomaly (Fig. 3e) indicates that the largest differences between DAILY and SMTH are located at the ice edge, where DAILY is more variable than SMTH. An exception is the presence of weak negative anomalies on an arc from $0^{\circ}$ to $180^{\circ} \mathrm{E}$, resulting from the earlier start of ice expansion in SMTH than DAILY. Figure $3 c$ displays the daily SIC evolution at a point in the East Siberian Sea (see dot in Fig. 3a) and shows that in much of September this region is ice free in both experiments. Subsequently, in the middle of October the ice concentration increases from around $10 \%$ to $100 \%$ in about 10 days in DAILY, whereas this takes about 20 days SMTH. In the Barents Sea (see dot in Fig. 3a), the difference between DAILY and SMTH is small, although the ice edge expansion is less continuous in DAILY than in SMTH (Fig. 3d).

The surface temperature (not shown) is warmer by several tenths of a degree in DAILY than in SMTH equatorward of the ice extent edge, where the surface is ocean in DAILY instead of sea ice (from $0^{\circ}$ to $180^{\circ} \mathrm{E}$ ), and it is also warmer over Norway, Sweden, and Finland. The 2-m air temperature (not shown) displays significant 


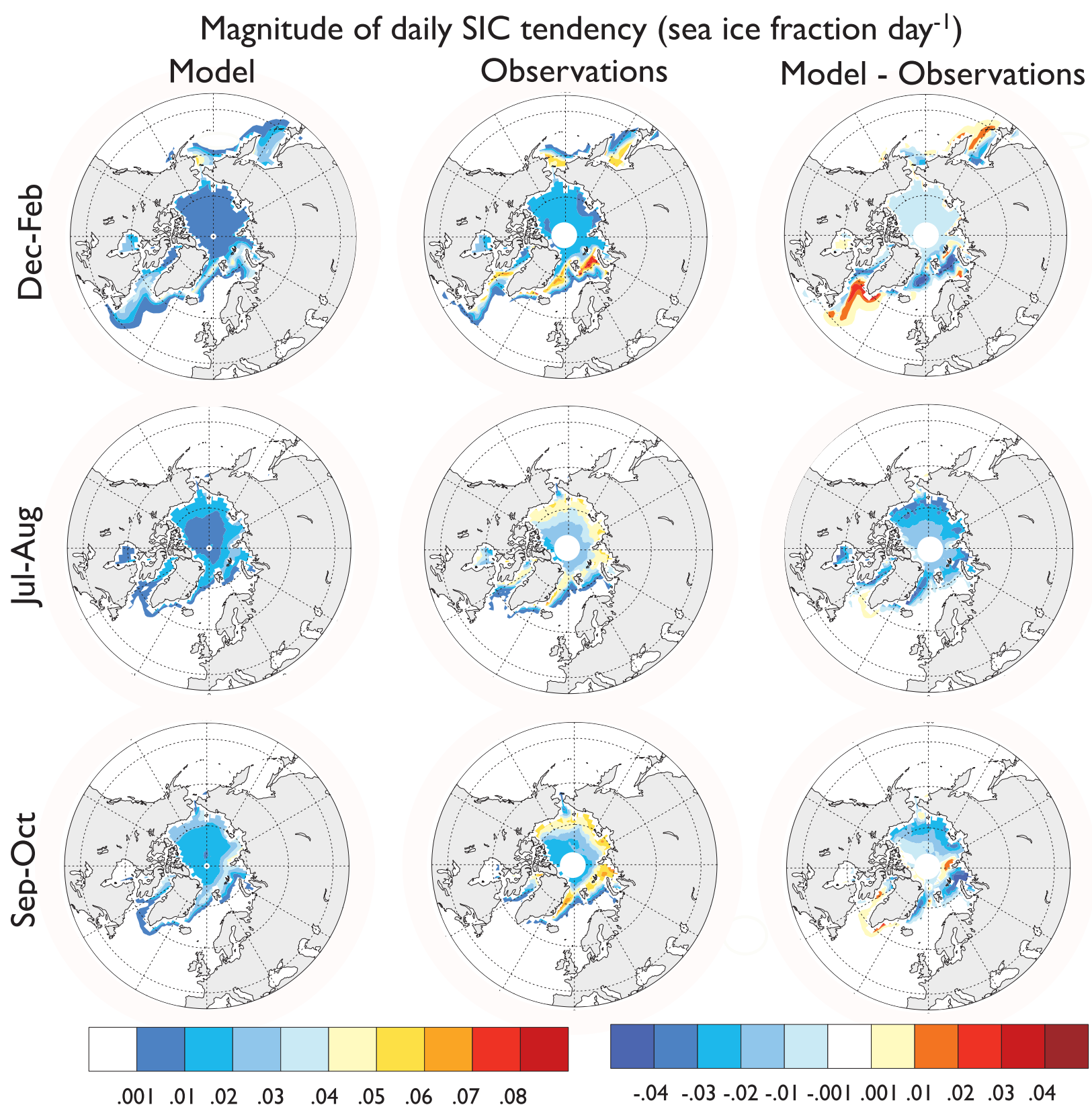

FIG. 2. Sea ice concentration tendency [see Eq. (1)] for (left) CCSM3.0 and (middle) observations. (right) SIC tendency anomalies defined as model minus observations. Mean and anomaly values are averaged for (top) DJF, (middle) July to August (JA), and (bottom) September to October (SO). Observational data voids are marked by the white circles. SIC data are from a twentieth-century control simulation (b30.004) and are evaluated for model years 1972-99. All panels have units of sea ice fraction per day.

positive temperature anomalies between 0.2 and $0.5 \mathrm{~K}$ collocated with the surface warming over Norway, Sweden, and Finland. There is weaker nonsignificant near-surface atmospheric warming in the Barents-Kara Seas $\left(70^{\circ}-90^{\circ} \mathrm{N}, 0^{\circ}-90^{\circ} \mathrm{E}\right)$ and an area of cooling $(\sim 0.4 \mathrm{~K})$ over the central Siberian uplands $\left(60^{\circ}-70^{\circ} \mathrm{N}, 90^{\circ}-120^{\circ} \mathrm{E}\right)$. The net surface heat flux (sensible + latent + longwave) anomaly is a positive (upward from surface) $3 \mathrm{~W} \mathrm{~m}^{-2}$ over north central Europe $\left(60^{\circ}-70^{\circ} \mathrm{N}, 30^{\circ}-60^{\circ} \mathrm{E}\right)$ (Fig. $\left.4 \mathrm{a}\right)$ and is primarily caused by enhanced longwave heat flux resulting from a warmer surface. The shortwave flux is not included in the calculated net heat flux because it is not relevant for understanding how the atmosphere is impacted from below. There is reduced heat flux out of the surface over the water bodies adjacent to Scandinavia (Fig. 4a), because of reduced latent heat loss from 
a)
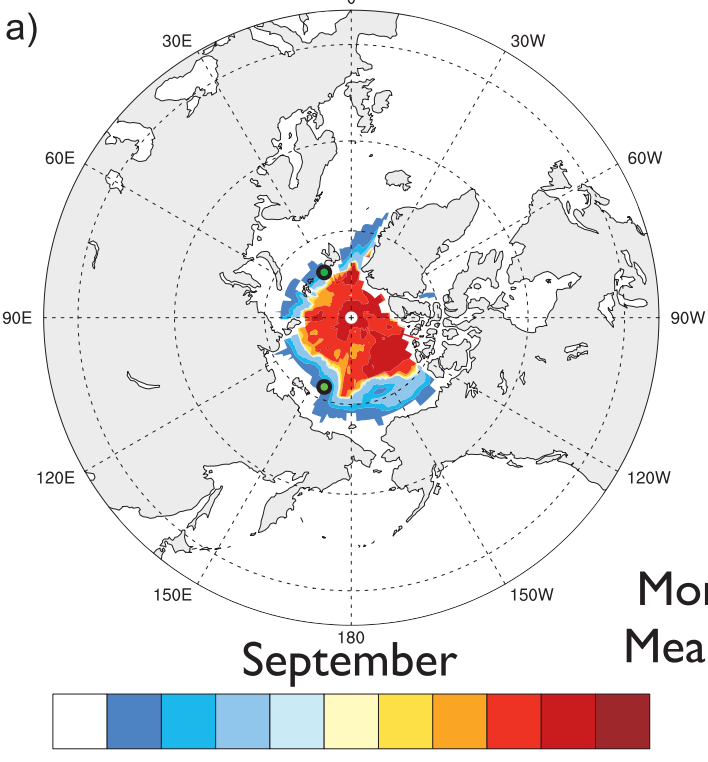

$\begin{array}{llllllllll}0.001 & 0.3 & 0.6 & 0.9 & 0.92 & 0.94 & 0.96 & 0.98 & 0.99 & 1\end{array}$

c)

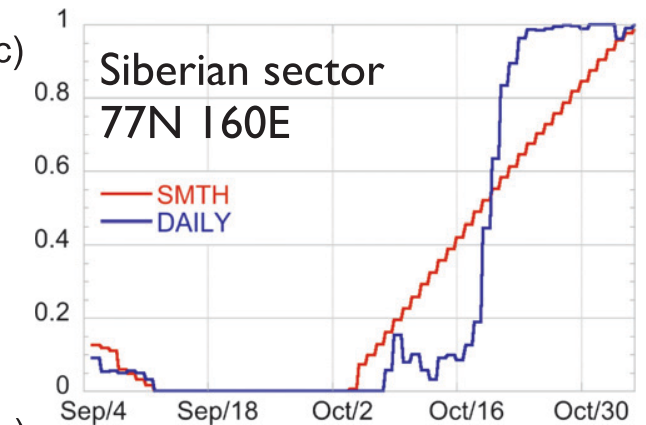

e)

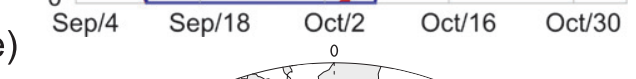

Monthly Mean SIC b)
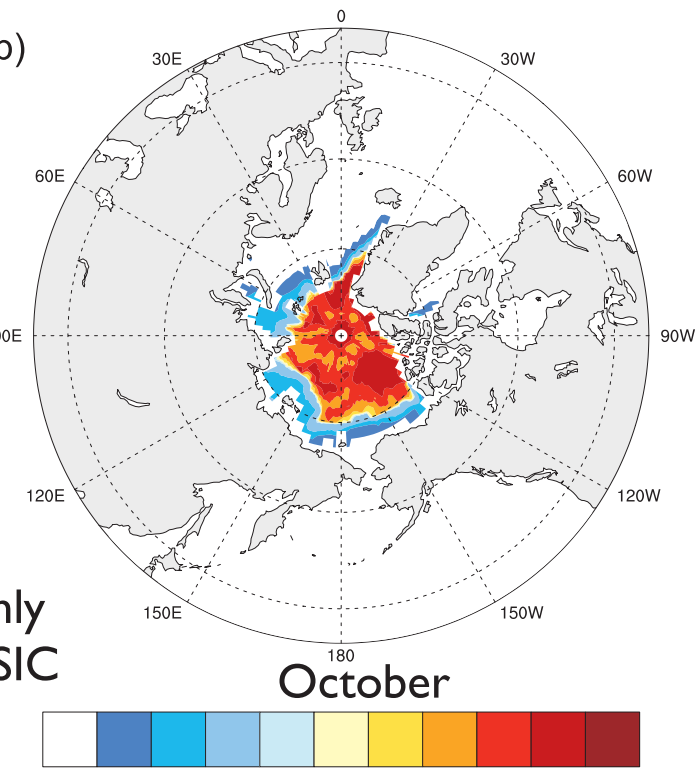

$\begin{array}{llllllllll}0.001 & 0.3 & 0.6 & 0.9 & 0.92 & 0.94 & 0.96 & 0.98 & 0.99 & 1\end{array}$

d)

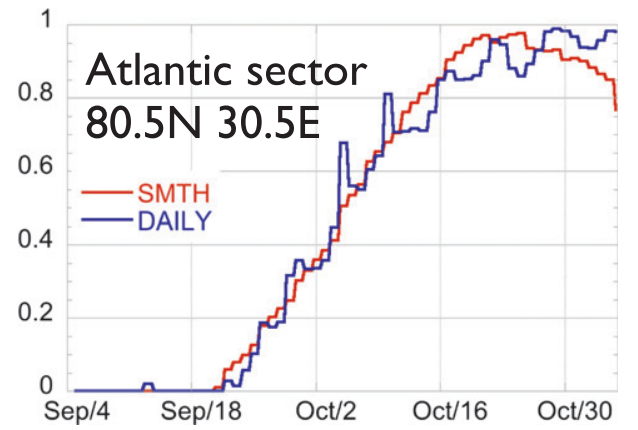

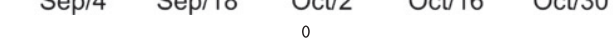
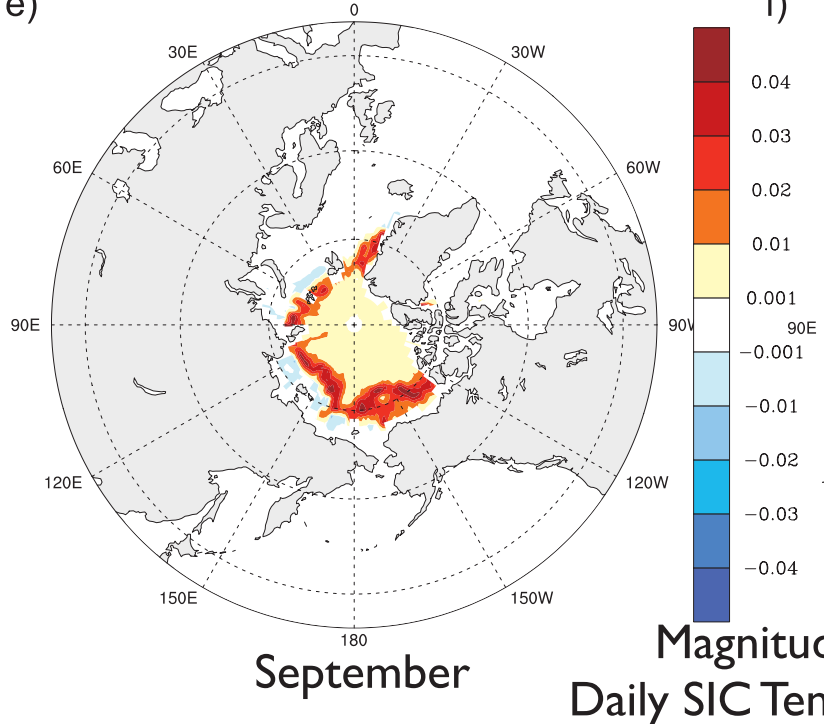

Magnitude Daily SIC Tendency

FIG. 3. Monthly mean sea ice concentration during (a) September and (b) October 2006. Daily SIC evolution in fall at the (c) East Siberian $\left(77^{\circ} \mathrm{N}, 160^{\circ} \mathrm{E}\right)$ and $(\mathrm{d})$ Barents Sea $\left(80.5^{\circ} \mathrm{N}, 30.5^{\circ} \mathrm{E}\right)$ grid points. The green dots with a black border in (a) identify the geographic location of the two time series in (c) and (d). Also shown are daily SIC tendency differences between daily and smooth (DAILY - SMTH) simulations for (e) September and (f) October 2006. The monthly mean sea ice concentration is nearly identical between the two simulations for these months but the daily variability is different. Units are in sea ice fraction for (a)-(d) and sea ice fraction per day for (e) and (f). 
a)

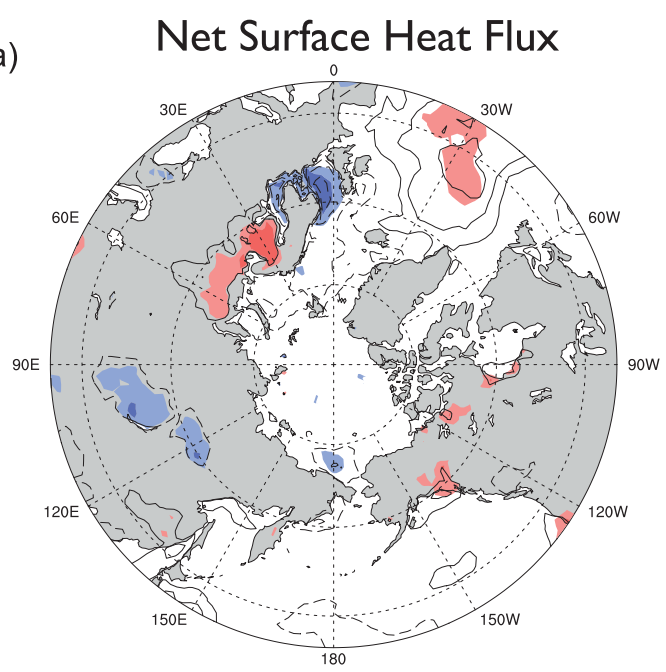

c) $\quad 500-1000 \mathrm{hPa}$ Thickness

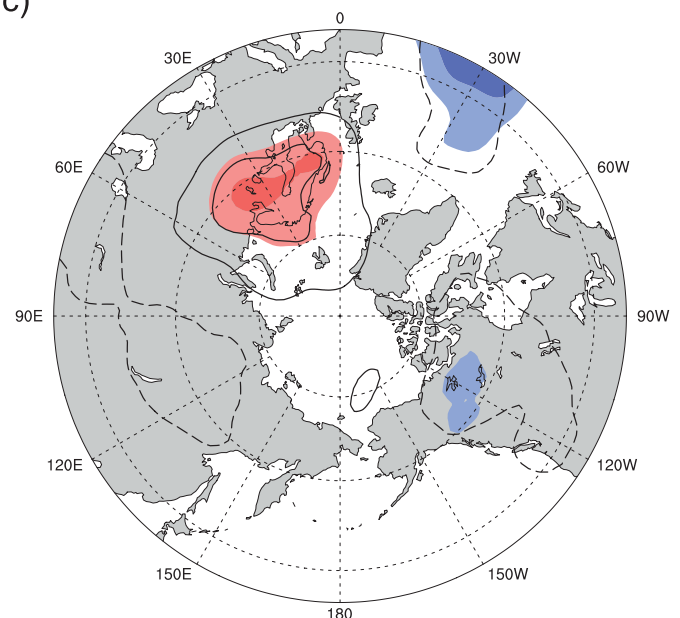

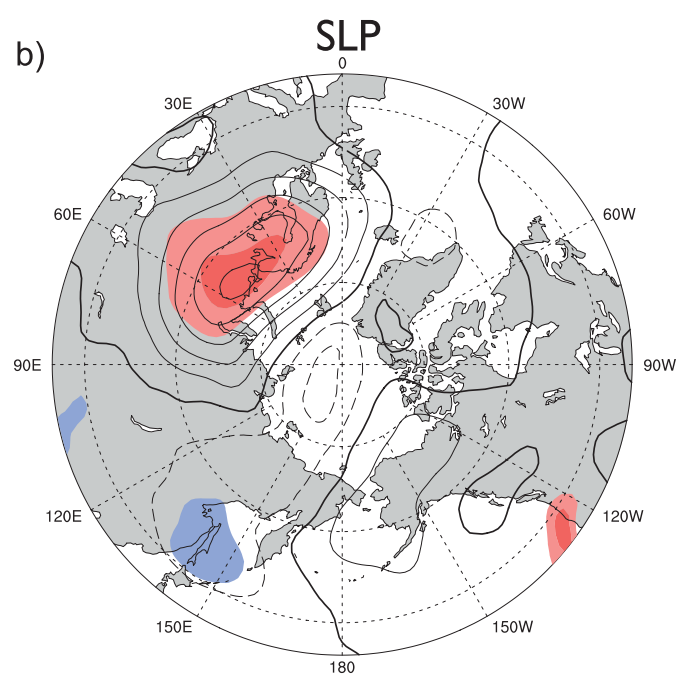

$200 \mathrm{hPa}$ Zonal Wind

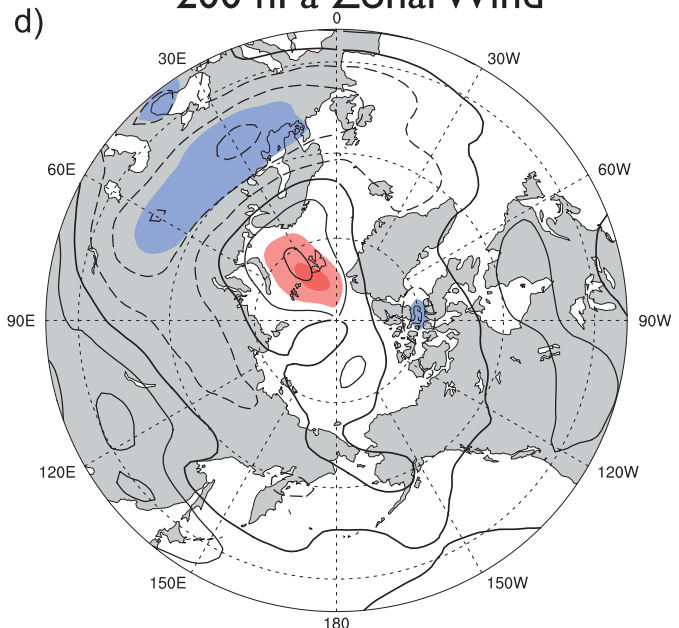

FIG. 4. September DAILY - SMTH anomalies of (a) net surface heat flux (latent + sensible + longwave), where positive values signify fluxes out of the surface $\left(\mathrm{W} \mathrm{m}^{-2}\right.$ ), (b) SLP (hPa), (c) 1000-500-hPa thickness (geopotential meters), and (d) 200-hPa zonal wind $\left(\mathrm{m} \mathrm{s}^{-1}\right)$. Dashed lines represent negative isolines and contour intervals are $3 \mathrm{~W} \mathrm{~m}^{-2}$ in (a), $0.5 \mathrm{hPa}$ in (b), $5 \mathrm{~m}$ in (c), and $0.8 \mathrm{~m} \mathrm{~s}^{-1}$ in (d). Light (dark) shading indicates statistical significance at the $95 \%(99 \%)$ or greater level based on a pooled variance $t$ test. Blue (red) shading corresponds to significant negative (positive) anomalies. Bold lines in (b) and (d) signify the zero contour line. No zero contour line is shown in (a) and (c).

the ocean surface. The net surface heat flux anomaly is negative over the central Siberian uplands $\left(60^{\circ}-70^{\circ} \mathrm{N}\right.$, $90^{\circ}-120^{\circ} \mathrm{E}$ ), primarily because of reduced longwave from a cooler surface as a response to reduced net solar radiation at the surface.

The key SLP anomaly feature for DAILY - SMTH is a positive maximum center of $2.5 \mathrm{hPa}$ located on land to the south of the Barents Sea (Fig. 4b). This anomalous circulation advects warmer southerly air over the Baltic and North Seas, which reduces the air-sea temperature contrast and is consistent with reduced heat flux out of the ocean in this region (Fig. 4a). There is a weak (not significant) low in the central Arctic, consistent with a thermal response to a warmer surface. The $500-\mathrm{hPa}$ anomaly pattern (not shown) is similar to the SLP pattern and is located over northern Europe with a central height of more than $30 \mathrm{~m}$. The 1000-500-hPa thickness displays positive height anomalies over northern Europe with an equivalent barotropic structure (Fig. 4c). The atmospheric response does not resemble a projection on natural modes of variability like the NAO found in Deser et al. (2010) and Seierstad and Bader (2009). Theoretical work has shown that an anomalous equivalent barotropic structure can be associated with an anomalous eddy circulation that leads to changes in storm tracks (Peng and Whitaker 1999). Total precipitation (not 

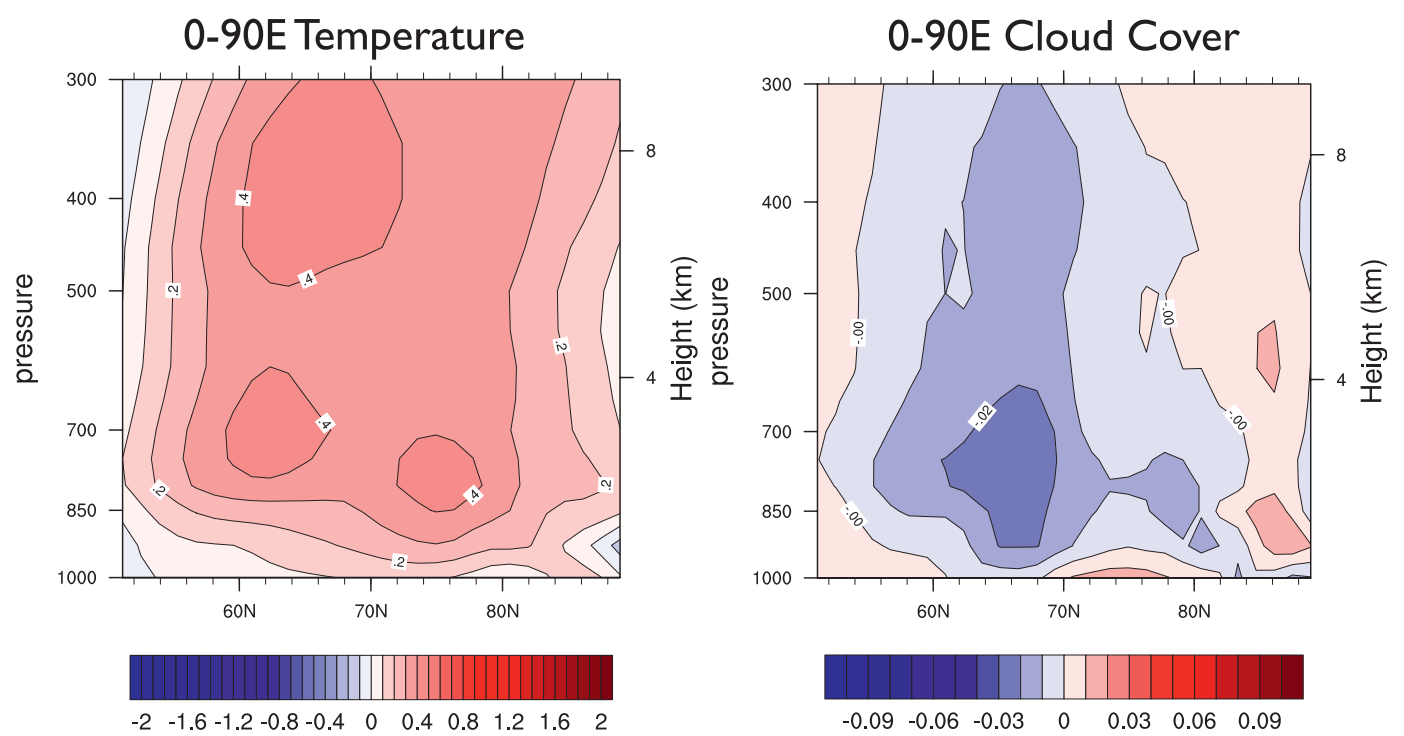

FIG. 5. September DAILY - SMTH anomalies of (a) air temperatures (K) and (b) cloud cover (fraction) zonally averaged from $0^{\circ}$ to $90^{\circ} \mathrm{E}$. Contour intervals are $0.1 \mathrm{~K}$ for (a) and 0.01 for (b).

shown) was significantly reduced (up to $2 \mathrm{~mm} \mathrm{day}^{-1}$ ) in the region of the anomalous high. The 200-hPa zonal wind anomaly indicates weaker winds of up to $2.0 \mathrm{~m} \mathrm{~s}^{-1}$ over parts of Europe and slightly stronger winds over the Barents Sea (Fig. 4d). The 200-hPa zonal winds are also weaker over the North Atlantic from $30^{\circ} \mathrm{W}$ to the prime meridian, although these anomalies are not statistically significant. The mean SMTH jet streak position (not shown) spans the North Atlantic $\left(\sim 45^{\circ}-55^{\circ} \mathrm{N}, 105^{\circ} \mathrm{W}-0^{\circ}\right)$ and is therefore reduced and retracted in DAILY compared with SMTH. Since storm development is favored on the poleward side of the exit region of a jet streak (see Bluestein 1993, 405-407), the reduced jet streak over the northern North Atlantic is therefore unfavorable for storm development over the northern northeast Atlantic. The vertical cross sections of zonally averaged air temperature and cloud cover between $0^{\circ}$ and $90^{\circ} \mathrm{E}$ were constructed to examine the response over the anomalous high pressure through the depth of the atmospheric column. North of $50^{\circ} \mathrm{N}$, the zonally averaged air temperature anomalies with height are primarily positive with maxima located well above the surface (Fig. 5a). Between $60^{\circ}$ and $70^{\circ} \mathrm{N}$ and from 950 to $650 \mathrm{hPa}$, cloud cover has decreased about $2 \%$ (Fig. 5b). The general warming of the Arctic atmospheric column is consistent with a weakened equator-to-pole temperature gradient and a reduced storm track in the North Atlantic. A weakened storm track response is supported by decreased 200-hPa zonal winds (Fig. 4d), precipitation (not shown), clouds at $850 \mathrm{hPa}$ (Fig. 5b), and poleward atmospheric heat transport represented by bandpassed $850-\mathrm{hPa} v^{\prime} T^{\prime}$ (transient eddies) (see Dammann 2011, Fig. 3.6b).

\section{2) OCTOBER}

The October 2006 monthly mean ice conditions (Fig. 3b) are similar to those of September (Fig. 3a). The DAILY - SMTH daily SIC tendency (Fig. 3f) indicates that DAILY is more variable at the ice edge than SMTH. The October sea ice edge in DAILY advances equatorward faster than in SMTH in the Siberian sector (Fig. 3c), which is consistent with Fig. 3f.

The 2-m temperature is cooler by up to $1.5 \mathrm{~K}$ over the Siberian seas, where DAILY ice cover expands equatorward faster than in SMTH (Fig. 6a) and is generally cooler over the high-latitude continental areas. The SLP and 500-hPa height responses (not shown), though weak and nonsignificant, have similar patterns with a low located over continental Eurasia $\left(30^{\circ}-120^{\circ} \mathrm{E}\right)$ and a high over the North Atlantic $\left(60^{\circ}-80^{\circ} \mathrm{N}, 60^{\circ} \mathrm{W}-30^{\circ} \mathrm{E}\right)$. The 1000-500-hPa thickness anomalies (Fig. 6b) exhibit a high over the North Atlantic and a weak low over western Eurasia. The zonal average temperature anomalies from $60^{\circ} \mathrm{E}$ to $180^{\circ}$ (Fig. 6c), the sector with the largest temperature response, indicate a cooler highlatitude atmospheric column where the strongest cooling is at the surface $(1.5 \mathrm{~K})$ and decreases with height. The zonally averaged $\left(60^{\circ} \mathrm{E}\right.$ to $\left.180^{\circ}\right)$ cloud cover anomalies are shallow at high latitudes, displaying negative anomalies up to $2 \%$ between $70^{\circ}$ and $80^{\circ} \mathrm{N}$ and below $850 \mathrm{hPa}$ (Fig. 6d). DAILY has faster ice growth in October than SMTH and the response in the atmosphere is indicative of a shallow local thermal response that is constrained close to the surface (e.g., cloud cover). This contrasts with the September response, which is 

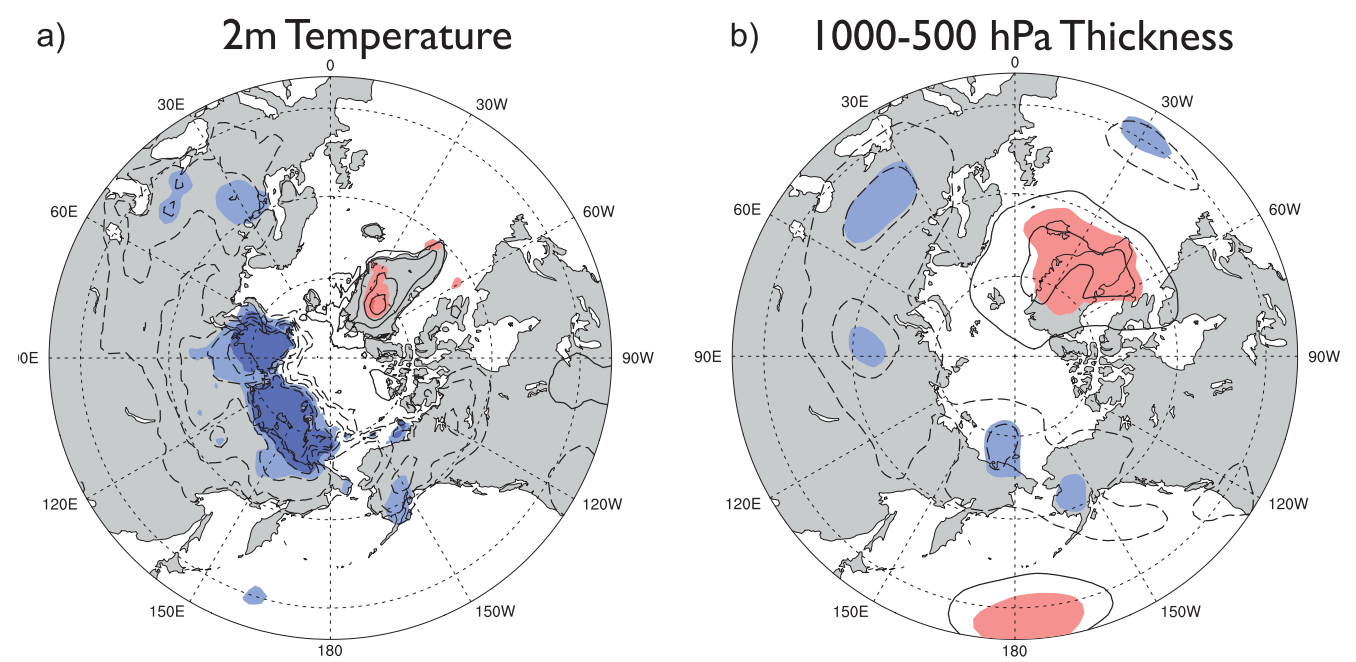

c) 60-I80E Temperature
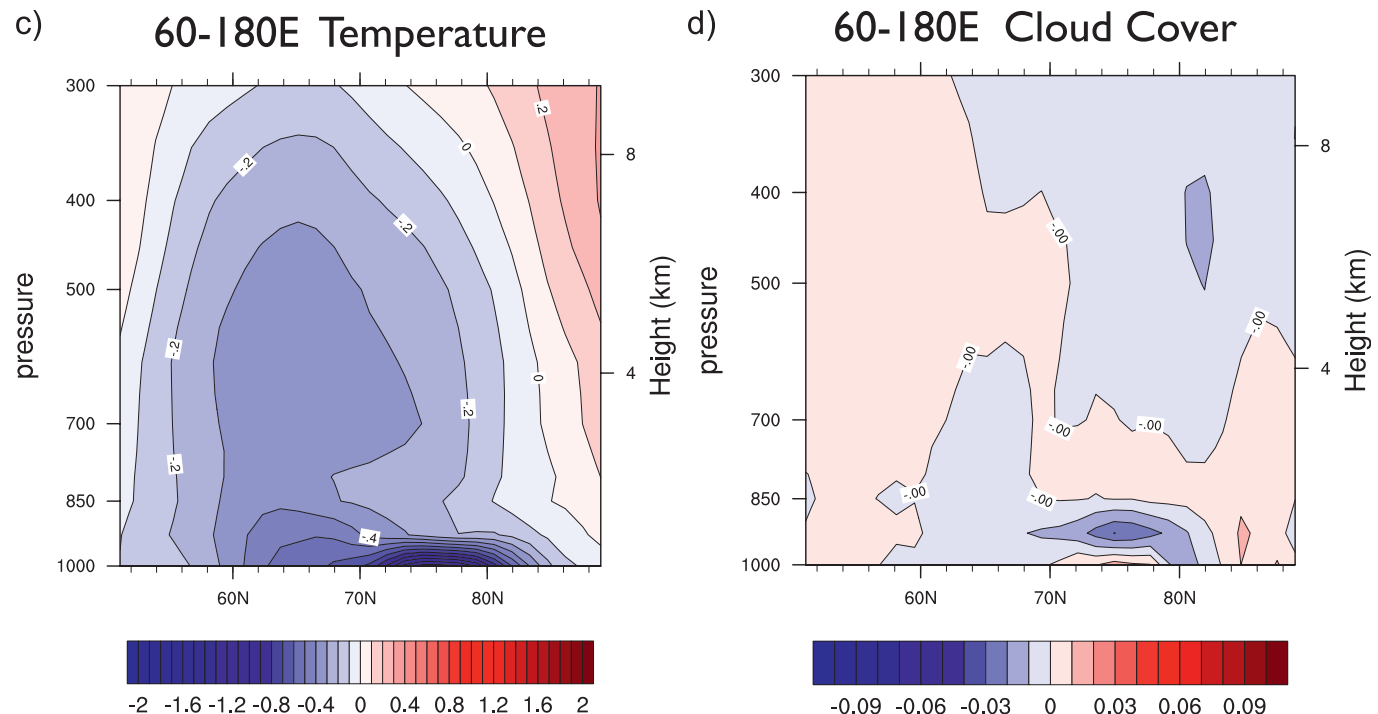

FIG. 6. October DAILY - SMTH anomalies of (a) 2-m temperature (K) and (b) 1000-500-hPa thickness (m). Vertical cross sections of zonally averaged $\left(60^{\circ} \mathrm{E}\right.$ to $\left.180^{\circ}\right)$ October DAILY - SMTH anomalies of (c) air temperatures (K) and (d) cloud cover (fraction). Dashed lines represent negative isolines in (a) and (b). Contour intervals are $0.2 \mathrm{~K}$ in (a), $5 \mathrm{~m}$ in (b), $0.1 \mathrm{~K}$ in (c), and 0.01 (fraction) in (d). Light (dark) shading indicates statistical significance at the $95 \%(99 \%)$ or greater level based on a pooled variance $t$ test in (a) and (b). Blue (red) shading corresponds to significant negative (positive) anomalies in (a) and (b). No zero contour line is shown in (a) and (b).

linked to the large-scale circulation through the storm tracks.

\section{c. Model response during winter (December-February)}

The DJF 2006/07 monthly mean ice concentration for DAILY (almost identical to SMTH) is shown in Fig. 7a and the DAILY - SMTH daily SIC tendency anomaly (Fig. 7b) shows the largest differences along the ice edge and differences of less than $1 \%$ concentration per day in the central Arctic. In the Barents Sea, the difference in ice edge fluctuations (DAILY - SMTH) is more pronounced during winter than during September-October (Figs. $3 e, f)$. The DJF sea ice edge in DAILY moves equatorward faster than in SMTH in the Chukchi Sea, similar to what happens in October in the East Siberian Sea (see Fig. 3c).

There are significant negative net surface heat flux (latent + sensible + longwave) anomalies (DAILY $\mathrm{SMTH})$ in the Chukchi-Bering Seas that reach $-6 \mathrm{~W} \mathrm{~m}^{-2}$ (not shown). Weak positive (less than $3 \mathrm{~W} \mathrm{~m}^{-2}$ ) net surface heat flux anomalies are found along the coast in the Laptev and East Siberian Seas (not shown), in a region with small differences (less than $1 \%$ day $^{-1}$ ) in the 

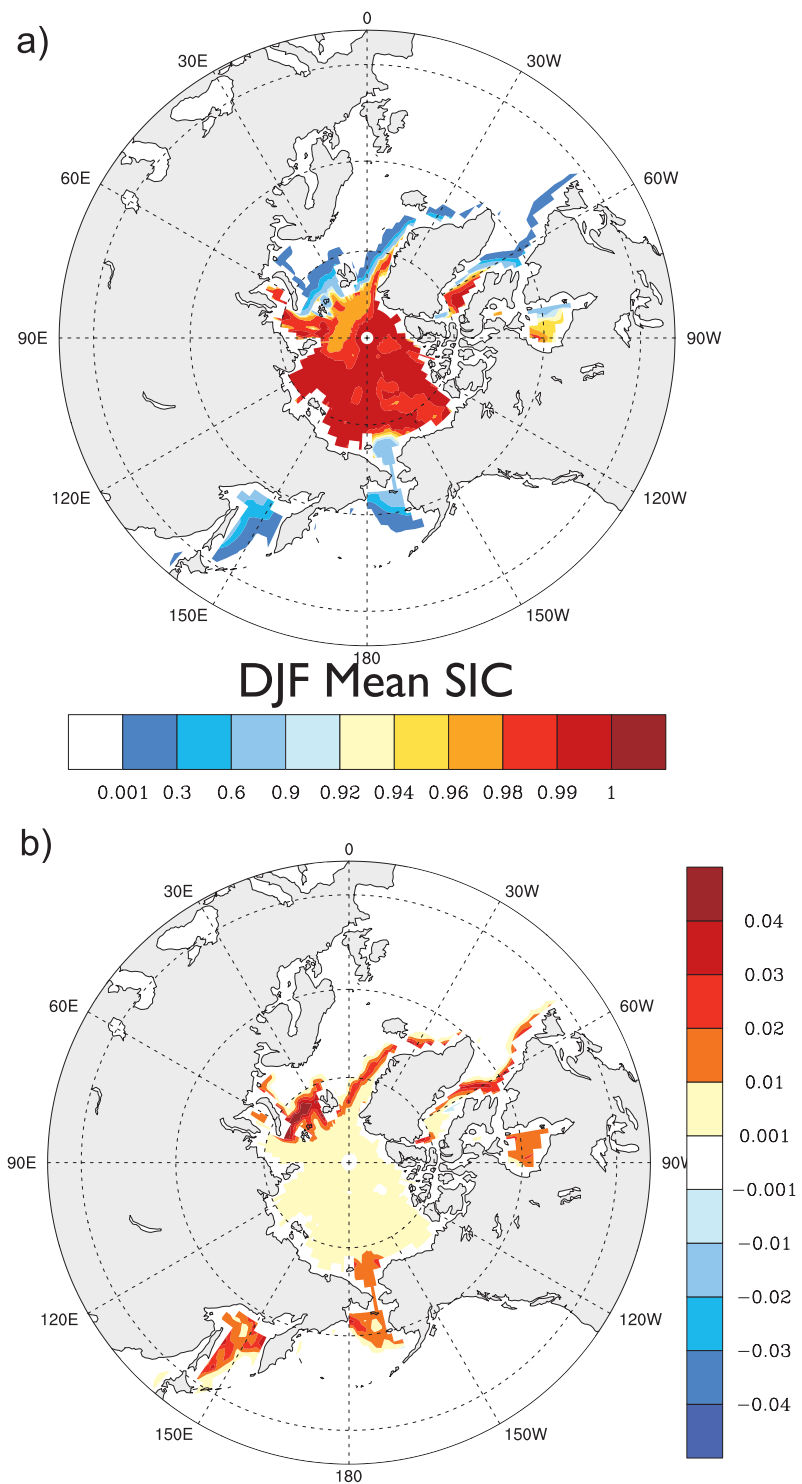

\section{DAILY-SMTH DJF Daily SIC Tendency}

FIG. 7. December-February 2006/07 (a) mean SIC and (b) daily sea ice concentration tendency anomaly (DAILY - SMTH). Units are in sea ice fraction in (a) and sea ice fraction per day in (b).

magnitude of SIC tendency anomalies (Fig. 7b). Sensible and latent heat flux anomalies are the primary contributors to the negative net heat flux anomalies in the Chukchi-Bering Seas, while longwave fluxes are the primary contributors to the positive net heat flux anomalies in the Laptev and East Siberian Seas. Both surface (not shown) and 2-m temperature (Fig. 8a) display positive anomalies over the Pacific sector of the Arctic and negative anomalies over the continental United States in the DAILY - SMTH plots. During winter, the climatological temperature difference, $T_{\text {diff }}=T_{\text {surface }}-T_{2 \text { meter }}$, is negative over sea ice and land and positive over the ocean. In other words, the ice or land surface is cooler than the overlying air temperature, with the opposite being true over the ocean. Temperature difference anomalies for DAILY SMTH are positive over the Arctic and negative over the Bering Sea, indicating that $T_{\text {diff }}$ is smaller in DAILY than SMTH (not shown). A smaller surface to air temperature difference is directly consistent with reduced sensible heat fluxes and indirectly consistent with reduced latent heat fluxes.

The difference in the atmospheric response between DAILY and SMTH is characterized by significant SLP anomalies (maximum $2 \mathrm{hPa}$ ) centered over Alaska and extending to the Great Lakes (Fig. 8b). The 1000-500-hPa thickness differences (Fig. 8c) show significant positive height anomalies over the Pacific sector of the Arctic and negative height anomalies over the continental United States. The significant ridge (Fig. 8b), characterized by an anomalous anticyclonic circulation, leads to increased flow of cold Arctic air into the western United States (Fig. 8a) and deepens the trough, resulting in anomalously cool temperatures over the west coast of the United States. These extend eastward as a result of the general westerly flow, contributing to reduced surface air temperatures over most of the continental United States in DAILY (Fig. 8a). Comparing the surface air temperature anomalies (not shown), DAILY CTRL and SMTH - CTRL reveal generally similar patterns in the Arctic but an opposite temperature response over the continental United States, with below normal values in DAILY - CTRL and above normal in SMTH - CTRL. It is noteworthy that these differing sea ice boundary conditions lead to strikingly different temperature anomalies over the continental United States and is especially relevant in light of recent studies that suggest that reduced Arctic sea ice leads to a more meridional wave pattern that may explain recent cold U.S. winters (Overland et al. 2011; Strey et al. 2010). Francis and Vavrus (2012) investigated Arctic amplification through $1000-500-\mathrm{hPa}$ thickness changes in the National Centers for Environmental Prediction (NCEP)NCAR data and found that amplified warming in the Arctic decreases the equator-to-pole thickness gradient, which weakens zonal upper-level flow. This slows eastward wave movement and increases the tendency for higher-amplitude meridional flow. The atmospheric column temperature anomalies, as deduced from thickness anomalies, are positive north of $60^{\circ} \mathrm{N}$ and negative to the south in DAILY - SMTH (Fig. 8c), which is consistent with the diagnosis of Francis and Vavrus (2012) as to what induces enhanced meridional flow.

Fang and Wallace (1994) found that less sea ice in the Bering Sea is correlated with a blocking ridge over 

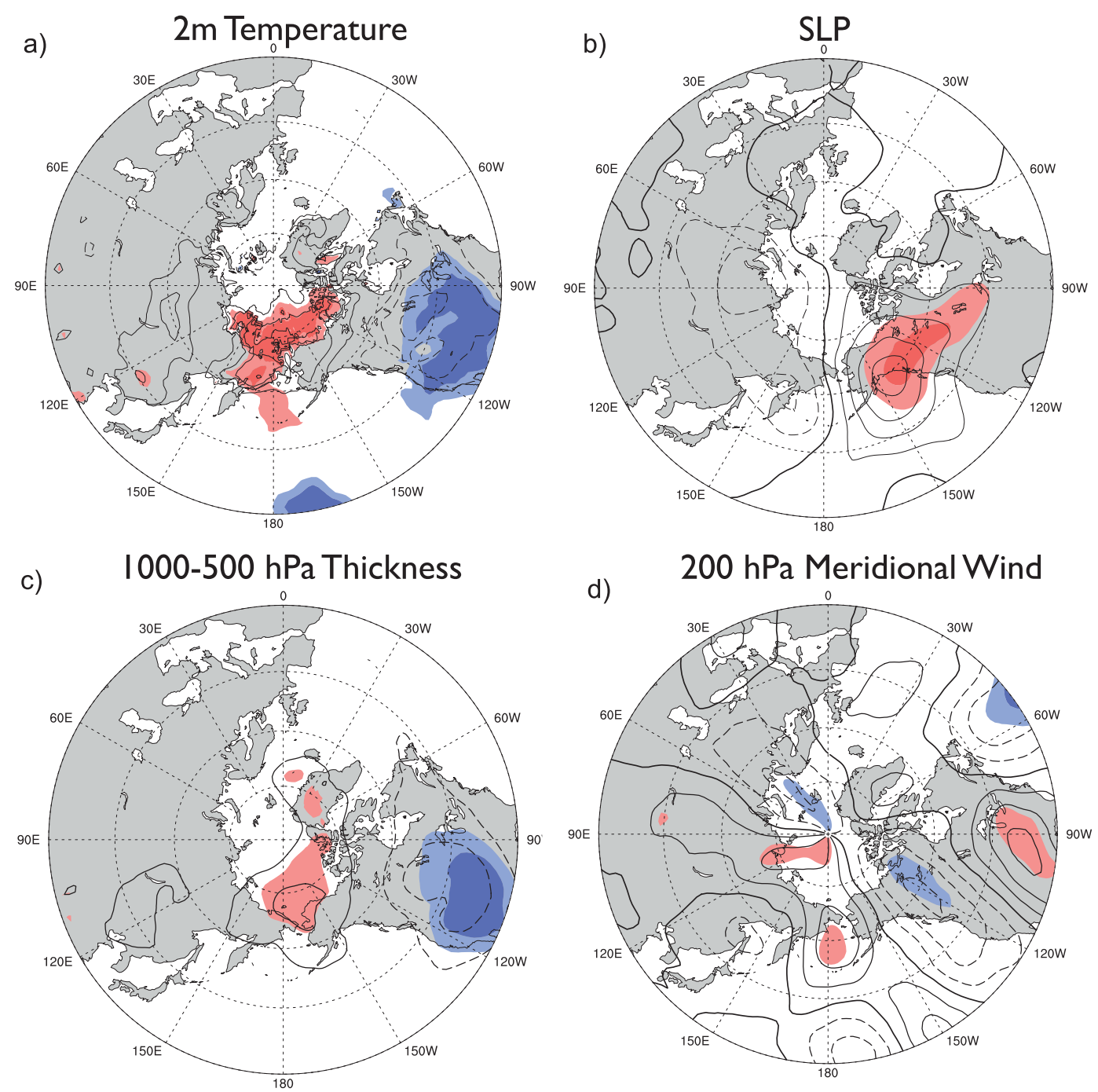

FIG. 8. DJF DAILY - SMTH anomalies of (a) 2-m temperature (K), (b) SLP (hPa), (c) 1000-500-hPa thickness (geopotential m), and (d) 200-hPa meridional wind $\left(\mathrm{m} \mathrm{s}^{-1}\right)$. Dashed lines represent negative isolines and contour intervals are $0.3 \mathrm{~K}$ in (a), $0.5 \mathrm{hPa}$ in (b), $5 \mathrm{~m}$ in (c), and $0.4 \mathrm{~m} \mathrm{~s}^{-1}$ in (d). Light (dark) shading indicates statistical significance at the $95 \%(99 \%)$ or greater level based on a pooled variance $t$ test. Blue (red) shading corresponds to significant negative (positive) anomalies. Bold lines in (b) and (d) signify the zero contour line. No zero contour lines are shown in (a) and (c).

Alaska and several recent studies also support this conclusion (Sasaki and Minobe 2005; Matthewman and Magnusdottir 2011). The winter 2006/07 sea ice concentration in the Bering Sea was slightly below normal [see Fig. D1 in Dammann (2011) for November-February ice anomalies, which are representative of the DJF ice anomalies]. SLP anomalies for DAILY - CTRL (Fig. 9a) and SMTH - CTRL (Fig. 9b) can be thought of as the atmospheric response to reduced sea ice in the Bering Sea, resulting in different responses in DAILY and SMTH. The SMTH - CTRL SLP anomalies are characterized by northerly flow in the central Bering Sea, which would lead to an increase in sea ice and constitute a negative feedback. In contrast, DAILY - CTRL SLP displays southerly flow in the west Bering Sea, which would act to reduce sea ice further in this region and thus represent a positive feedback. As mentioned in the introduction, Honda et al. (1999) and Alexander et al. (2004) found the atmospheric response to be a positive feedback for the ice (i.e., greater sea ice in the Bering Sea induces a circulation that leads to more northerly flow, which in turn advects ice from north to south). While the seemingly small differences in ice variability between the experiments lead to a negative feedback in the case of SMTH - CTRL (Fig. 9b), they produce a weakly positive feedback in DAILY - CTRL (Fig. 9a). 

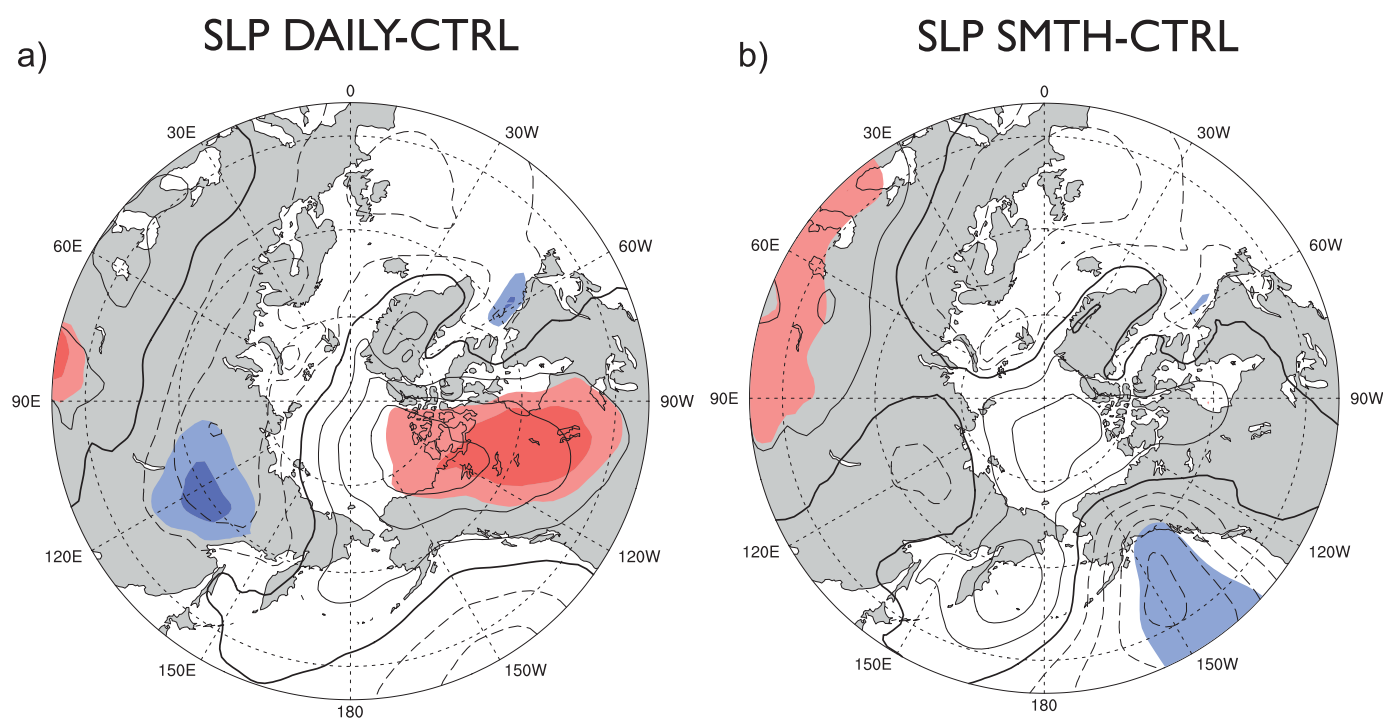

FIG. 9. DJF SLP (hPa) for (a) DAILY - CTRL and (b) SMTH - CTRL. The contour interval is $0.5 \mathrm{hPa}$. Light (dark) shading indicates statistical significance at the $95 \%(99 \%)$ or greater level based on a pooled variance $t$ test. Blue (red) shading corresponds to significant negative (positive) anomalies. The bold line signifies the zero contour line.

These differences in the sign of the ice-atmosphere feedback demonstrate just how the details of sea ice evolution can influence the climate response.

\section{Conclusions}

This study investigated the day-to-day variability of sea ice concentration in five Coupled Model Intercomparison Project phase 5 (CMIP5) simulations and the Community Climate System Model (CCSM3.0 and CCSM4.0) and found that coupled models generally underestimate this variability particularly in the marginal ice zone. This is relevant as coupled climate models are being used to develop seamless daily-to-seasonal sea ice forecasts and suggests that further work is needed to diagnose the source of this deficiency. Generally, model deficiencies arise from various factors (e.g., atmospheric forcing or oceanic forcing) but a prime candidate in this case is the ice rheology, which may not allow enough mobility, particularly in the marginal ice zone. There is promise of improved lead formation in a new elasticdecohesive constitutive ice model (Schreyer et al. 2006), which is currently being tested for use in CCSM4.0.

To investigate to what extent the underestimated variability impacts the atmosphere, a modified version of the Community Atmosphere Model (CAM3.0) was forced with prescribed sea ice both with and without daily fluctuations. Two 100-member ensemble experiments were forced with daily varying (DAILY) and smoothly varying (SMTH) sea ice, for an anomalously low ice period
(August 2006-November 2007), along with a continuous climatological (1982-2007) 100-yr control run. Analysis of the results focused on three periods: September 2006, October 2006, and December-February 2006/07.

In September 2006, the ice edge fluctuation differences between DAILY and SMTH led to weak warming in the Barents-Kara Seas in DAILY - SMTH. North of the ice edge, a weak thermal response consisting of a weak low pressure was produced. To the south of the Barents-Kara Seas over land, an SLP anomaly of $2.5 \mathrm{hPa}$ over northern Europe consistent with reduced precipitation and a northward shift in the storm tracks was generated. During October 2006, the ice expands equatorward faster in DAILY than SMTH, leading to nearsurface cooling that penetrates up to $300 \mathrm{hPa}$.

The most dramatic differences in the atmospheric response between DAILY and SMTH sea ice occurred in DJF in the Pacific sector. Sea ice variations in the Bering-Chukchi seas are associated with downstream positive SLP anomalies in DAILY - CTRL but negative anomalies in SMTH - CTRL. In DAILY - CTRL, the upper-level flow is strongly meridional, which advects cool air over the continental United States. In contrast, the temperatures over the continental United States are anomalously warm in SMTH - CTRL. Obtaining the opposite response with fairly subtle differences in forcing suggests that the atmosphere is sensitive to the nature of the sea ice forcing.

We were not successful at identifying changes in atmospheric response linked to the frequency of the sea 
ice forcing, although this was explored during the course of our study. Seiffert and von Storch (2008) examined the impact of adding white noise to small-scale atmospheric fluctuations and found that climate sensitivity to increased $\mathrm{CO}_{2}$ was weaker when the fluctuations were increased. In contrast, they found that reducing the horizontal diffusion (which also increases small-scale variability) increased the model sensitivity. Their study highlights the sensitivity of the atmosphere to the nature of small-scale variations and demonstrates that they can have significant impacts on modeled climate processes.

This study provides motivation to advance sea ice models that incorporate adequate observations, suggests caution when investigating the atmospheric impact of sea ice in climate models, and highlights the need to understand how ice conditions impact the atmosphere.

Acknowledgments. This material is based upon work supported by the National Science Foundation under Grant 0904411. Any opinions, findings, and conclusions or recommendations expressed in this material are those of the authors and do not necessarily reflect the views of the National Science Foundation. This work was also funded through a graduate research assistantship and a grant of High Performance Computing (HPC) resources from the Arctic Region Supercomputing Center as a part of the Department of Defense HPC Modernization Program. This research uses data and a model provided by the Community Climate System Model project (http:// www.cesm.ucar.edu), supported by the Directorate for Geosciences of the National Science Foundation and the Office of Biological and Environmental Research of the U.S. Department of Energy. NOAA ERSST, version 3, data were provided by the NOAA/OAR/ESRL PSD, Boulder, Colorado, USA, on their website at http:// www.esrl.noaa.gov/psd. We acknowledge the World Climate Research Programme's Working Group on Coupled Modelling, which is responsible for CMIP, and we thank the climate modeling groups (listed in Table 1 of this paper) for producing and making available their model output. The U.S. Department of Energy's Program for Climate Model Diagnosis and Intercomparison provides coordinating support for CMIP and led development of software infrastructure in partnership with the Global Organization for Earth System Science Portals. We thank three anonymous reviewers whose careful comments improved our paper significantly. We thank Dr. Josefino Comiso for providing daily sea ice data.

\section{REFERENCES}

Alexander, M. A., U. S. Bhatt, J. E. Walsh, M. S. Timlin, J. S. Miller, and J. D. Scott, 2004: The atmospheric response to realistic Arctic sea ice anomalies in an AGCM during winter. J. Climate, 17, 890-905.

Alexeev, V. A., P. L. Langen, and J. R. Bates, 2005: Polar amplification of surface warming on an aquaplanet in "ghost forcing" experiments without sea ice feedbacks. Climate Dyn., 24, 655-666, doi:10.1007/s00382-005-0018-3.

Balmaseda, M. A., L. Ferranti, F. Molteni, and T. N. Palmer, 2010: Impact of 2007 and 2008 Arctic ice anomalies on the atmospheric circulation: Implications for long-range predictions. Quart. J. Roy. Meteor. Soc., 136, 1655-1664.

Barsugli, J. J., and D. S. Battisti, 1998: The basic effects of atmosphereocean thermal coupling on midlatitude variability. J. Atmos. Sci., 55, 477-493.

Benestad, R. E., R. Senan, M. Balmesada, L. Ferranti, Y. Orsolini, and A. Melsom, 2011: Sensitivity of summer 2-m temperature to sea ice conditions. Tellus, 63A, 324-337, doi:10.1111/j.16000870.2010.00488.x.

Bhatt, U. S., M. A. Alexander, D. S. Battisti, D. D. Houghton, and L. M. Keller, 1998: Atmosphere-ocean interaction in the North Atlantic: Near-surface climate variability. J. Climate, 11, 1615-1632.

, — , C. Deser, J. E. Walsh, J. S. Miller, M. S. Timlin, J. Scott, and R. A. Tomas, 2008: The atmospheric response to realistic reduced summer arctic sea ice anomalies. Arctic Sea Ice Decline: Observations, Projections, Mechanisms, and Implications, Geophys. Monogr., Vol. 180, Amer. Geophys. Union, 91-110.

Bluestein, H. B., 1993: Observations and Theory of Weather Systems. Vol. 2, Synoptic-Dynamic Meteorology in Midlatitudes, Oxford University Press, $594 \mathrm{pp}$.

Blüthgen, J., R. Gerdes, and M. Werner, 2012: Atmospheric response to the extreme Arctic sea ice conditions in 2007. Geophys. Res. Lett., 39, L02707, doi:10.1029/2011GL050486.

Briegleb, B. P., C. M. Bitz, E. C. Hunke, W. H. Lipscomb, M. M. Holland, J. L. Schramm, and R. E. Moritz, 2004: Scientific description of the sea ice component in the Community Climate System Model, version 3. NCAR Tech. Note NCAR/ TN-463+STR, 70 pp.

Collins, W. D., and Coauthors, 2006a: The Community Climate System Model version 3 (CCSM3). J. Climate, 19, 2122-2143. , and Coauthors, 2006b: The formulation and atmospheric simulation of the Community Atmosphere Model version 3 (CAM3). J. Climate, 19, 2144-2161.

Comiso, J. C., and F. Nishio, 2008: Trends in the sea ice cover using enhanced and compatible AMSR-E, SSM/I, and SMMR data. J. Geophys. Res., 113, C02S07, doi:10.1029/2007JC004257.

Dammann, D. O., 2011: Role of arctic sea ice variability in climate models. M.S. thesis, Department of Atmospheric Sciences, University of Alaska Fairbanks, 152 pp. [Available online at ffden-2.phys.uaf.edu/atm/Students/theses/Dammann_ MS.pdf.]

Deser, C., J. E. Walsh, and M. S. Timlin, 2000: Arctic sea ice variability in the context of recent atmospheric circulation trends. J. Climate, 13, 617-633.

, G. Magnusdottir, R. Saravanan, and A. Phillips, 2004: The effects of North Atlantic SST and sea ice anomalies on the winter circulation in CCM3. Part II: Direct and indirect components of the response. J. Climate, 17, 877-889.

$\longrightarrow$, R. Tomas, M. Alexander, and D. Lawrence, 2010: The seasonal atmospheric response to projected arctic sea ice loss in the late twenty-first century. J. Climate, 23, 333-351.

Dickinson, R. E., K. W. Oleson, G. Bonan, F. Hoffman, P. Thornton, M. Vertenstein, Z.-L. Yang, and X. Zeng, 2006: 
The Community Land Model and its climate statistics as a component of the Community Climate System Model. J. Climate, 19, 2302-2324.

Druckenmiller, M. L., H. Eicken, J. C. George, and L. Brower, 2010: Assessing the shorefast ice: Inupiat whaling trails off Barrow, Alaska. SIKU: Knowing Our Ice-Documenting Inuit Sea Ice Knowledge and Use, I. Krupnik et al., Eds., SpringerVerlag, 203-228.

Fang, Z., and J. M. Wallace, 1994: Arctic sea ice variability on a timescale of weeks and its relation to atmospheric forcing. J. Climate, 7, 1897-1914.

Francis, J. A., and S. J. Vavrus, 2012: Evidence linking arctic amplification to extreme weather in mid-latitudes. Geophys. Res. Lett., 39, L06801, doi:10.1029/2012GL051000.

Hack, J. J., J. M. Caron, G. Danabasoglu, K. W. Oleson, C. Bitz, and J. E. Truesdale, 2006: CCSM-CAM3 climate simulation sensitivity to changes in horizontal resolution. J. Climate, 19, 2267-2289.

Higgins, M. E., and J. J. Cassano, 2012: Northern Alaskan land surface response to reduced arctic sea ice extent. Climate Dyn., 38, 2099-2113, doi:10.1007/s00382-011-1095-0.

Holland, M. M., C. M. Bitz, E. C. Hunke, W. H. Lipscomb, and J. L. Schramm, 2006a: Influence of the sea ice thickness distribution on polar climate in CCSM3. J. Climate, 19, 2398-2414.

,-- , and B. Tremblay, 2006b: Future abrupt reductions in the summer Arctic sea ice. Geophys. Res. Lett., 33, L23503, doi:10.1029/2006GL028024.

Honda, M., K. Yamazaki, H. Nakamura, and K. Takeuchi, 1999: Dynamic and thermodynamic characteristics of the atmospheric response to anomalous sea-ice extent in the Sea of Okhotsk. J. Climate, 12, 3347-3358.

Hunke, E. C., and W. H. Lipscomb, 2010: CICE: The Los Alamos Sea Ice Model documentation and software user's manual version 4.1. Los Alamos National Laboratory Rep. LA-CC06-012, 76 pp. [Available online at http://oceans11.lanl.gov/ trac/CICE.]

Kauffman, B. G., and W. G. Large, 2002: The CCSM coupler, version 5.0.1: Combined user's guide, source code reference, and scientific description. National Center for Atmospheric Research, 46 pp. [Available online at http://www.cesm.ucar. edu/models/ccsm2.0.1/cpl5/users_guide.pdf.]

Knell, N. F., 2008: The reemergence of the Arctic as a strategic location. Monograph, School of Advanced Military Studies, U.S. Army Command and General Staff College, 111 pp. [Available online at http://www.dtic.mil/cgi-bin/GetTRDoc? Location $=\mathrm{U} 2 \&$ doc $=$ GetTRDoc.pdf $\& A D=A D A 494394$. $]$

Kumar, A., and Coauthors, 2010: Contribution of sea ice loss to Arctic amplification. Geophys. Res. Lett., 37, L21701, doi:10.1029/ 2010GL045022.

Kwok, R., and D. A. Rothrock, 2009: Decline in Arctic sea ice thickness from submarine and ICESat records: 1958-2008. Geophys. Res. Lett., 36, L15501, doi:10.1029/2009GL039035.

Magnusdottir, G., C. Deser, and R. Saravanan, 2004: The effects of North Atlantic SST and sea ice anomalies on the winter circulation in CCM3. Part I: Main features and storm track characteristics of the response. J. Climate, 17, 857-876.

Massonnet, F., T. Fichefet, H. Goosse, C. M. Bitz, G. PhilipponBerthier, M. M. Holland, and P.-Y. Barriat, 2012: Constraining projections of summer Arctic sea ice. Cryosphere, 6, 1383-1394, doi:10.5194/tc-6-1383-2012.

Matthewman, N. J., and G. Magnusdottir, 2011: Observed interaction between Pacific sea ice and the western Pacific pattern on intraseasonal time scales. J. Climate, 24, 5031-5042.
Orsolini, Y., R. Senan, R. Benestad, and A. Melsom, 2011: Autumn atmospheric response to the 2007 low Arctic sea ice extent in coupled ocean-atmosphere hindcasts. Climate Dyn., 38, 24372448, doi:10.1007/s00382-011-1169-z.

Overland, J. E., K. R. Wood, and M. Wang, 2011: Warm Arcticcold continents: Climate impacts of the newly open Arctic Sea. Polar Res., 30, 15787, doi:10.3402/polar.v30i0.15787.

Peng, S. L., and J. S. Whitaker, 1999: Mechanisms determining the atmospheric response to midlatitude SST anomalies. J. Climate, 12, 1393-1408.

Petoukhov, V., and V. A. Semenov, 2010: A link between reduced Barents-Kara sea ice and cold winter extreme over northern continents. J. Geophys. Res., 115, D21111, doi:10.1029/ 2009JD013568.

Polyakov, I. V., A. V. Pnyushkov, R. Rember, V. V. Ivanov, Y.-D. Lenn, L. Padman, and E. C. Carmack, 2012: Mooring-based observations of double-diffusive staircases over the Laptev Sea slope. J. Phys. Oceanogr., 42, 95-109.

Rinke, A., W. Maslowski, K. Dethloff, and J. Clement, 2006: Influence of sea ice on the atmosphere: A study with an Arctic atmospheric regional climate model. J. Geophys. Res., 111, D16103, doi:10.1029/2005JD006957.

Rothrock, D. A., D. B. Percival, and M. Wensnahan, 2008: The decline in arctic sea-ice thickness: Separating the spatial, annual, and interannual variability in a quarter century of submarine data. J. Geophys. Res., 113, C05003, doi:10.1029/ 2007JC004252.

Sardeshmukh, P. D., G. P. Compo, and C. Penland, 2000: Changes of probability associated with El Niño. J. Climate, 13, 42684286.

Sasaki, Y. N., and S. Minobe, 2005: Seasonally dependent interannual variability of sea ice in the Bering Sea and its relation to atmospheric fluctuations. J. Geophys. Res., 110, C05011, doi:10.1029/2004JC002486.

Schreyer, H. L., D. L. Sulsky, L. B. Munday, M. D. Coon, and R. Kwok, 2006: Elastic-decohesive constitutive model for sea ice. J. Geophys. Res., 111, C11S26, doi:10.1029/2005JC003334.

Screen, J. A., and I. Simmonds, 2010: Increasing fall-winter energy loss from the Arctic Ocean and its role in Arctic temperature amplification. Geophys. Res. Lett., 37, L16707, doi:10.1029/ $2010 \mathrm{gl} 1044136$.

_ C. Deser, and I. Simmonds, 2012: Local and remote controls on observed Arctic warming. Geophys. Res. Lett., 39, L10709, doi:10.1029/2012GL051598.

Sedláček, J., R. Knutti, O. Martius, and U. Beyerle, 2012: Impact of a reduced arctic sea ice cover on ocean and atmospheric properties. J. Climate, 25, 307-319.

Seierstad, I., and J. Bader, 2009: Impact of a projected future Arctic sea ice reduction on extratropical storminess and the NAO. Climate Dyn., 33, 937-943, doi:10.1007/s00382-008-0463-x.

Seiffert, R., and J.-S. von Storch, 2008: Impact of atmospheric small-scale fluctuations on climate sensitivity. Geophys. Res. Lett., 35, L10704, doi:10.1029/2008GL033483.

Serreze, M. C., and R. G. Barry, 2011: Processes and impacts of Arctic amplification: A research synthesis. Global Planet Change, 77, 85-96, doi:10.1016/j.gloplacha.2011.03.004.

Singarayer, J. S., J. L. Bamber, and P. J. Valdes, 2006: Twenty-firstcentury climate impacts from a declining Arctic sea ice cover J. Climate, 19, 1109-1125.

Smith, R. D., and P. R. Gent, 2002: Reference manual for the Parallel Ocean Program (POP), ocean component of the Community Climate System Model (CCSM2.0). Tech. Rep. LAUR-02-2484, 73 pp. [Available online at 
http://www.cesm.ucar.edu/models/ccsm2.0.1/pop/doc/sci_ref_ manual.pdf.]

Smith, T. M., R. W. Reynolds, T. C. Peterson, and J. Lawrimore, 2008: Improvements to NOAA's historical merged landocean surface temperature analysis (1880-2006). J. Climate, 21, 2283-2296.

Strey, S. T., W. L. Chapman, and J. E. Walsh, 2010: The 2007 sea ice minimum: Impacts on the Northern Hemisphere atmosphere in late autumn and early winter. J. Geophys. Res., 115, D23103, doi:10.1029/2009jd013294.
Stroeve, J., M. Serreze, S. Drobot, S. Gearheard, M. Holland, J. Maslanik, W. Meier, and T. Scambos, 2008: Arctic sea ice extent plummets in 2007. Eos, Trans. Amer. Geophys. Union, 89, 13, doi:10.1029/2008EO020001.

Taylor, K. E., R. J. Stouffer, and G. A. Meehl, 2012: An overview of CMIP5 and the experiment design. Bull. Amer. Meteor. Soc., 93, 485-498.

Vavrus, S. A., U. S. Bhatt, and V. A. Alexeev, 2011: Factors influencing simulated changes in future arctic cloudiness. J. Climate, 24, 4817-4830. 